\title{
Understanding the SituATion On the Ground
}

\author{
Mansurah Izzul Mohamed \\ Northeastern University
}

\begin{abstract}
Mansurah Izzul Mohamed comments on the implementation of Syariah Penal Code Order 2013-Brunei's new Islamic criminal code. Phase One, covering small crimes and misdemeanors, took effect in May 2014. Phases Two and Three, specifying more serious crimes and more severe punishments, took effect in April 2019. This post outlines the history and procedural components of the law with respect to national and international law. Her basic argument is that Codification + Procedure = Just Implementation .
\end{abstract}


International attention to Brunei's plan to pass a new Islamic criminal code peaked in May 2014. That was Phase One, when the country had just announced the legislation. The attention returned in April 2019, as the country went on to pass into law Phases Two and Three. ${ }^{1}$

One part of the story is missing: even before the Syariah (Sharī'a) Penal Code Order (SPCO) of 2013, components of Islamic law in Brunei were present through customary norms-well before the country attained protectorate status from the British in 1888, and independence in 1984. Under the British protectorate, residents and colonial officers alike would advise the Sultan on religious administration. They sought to systematically institutionalize and codify Islamic laws, following Western ideas of nation building and particular types of law. ${ }^{2}$ To be sure, until 2014, the Islamic legal sphere was confined to family and personal status law. But the colonial influence provided an institutional foundation for the creation of post-colonial Islamization policies thereafter.

\section{Codification of ISLAMic Principles ${ }^{3}$}

What Brunei has done with respect to the codification of Islamic principles into law is to allow for a uniform and clarified interpretation that can provide legislative mechanisms to improve criminal law practices and informal norms. The codification established that the authority to amend the legislation would be with the national government and not an individual judge.

While still in the primary stages of implementation, the new law in Brunei is one in which criminal law tracks the community's judgments of justice in order to build legitimacy locally. Paul

$1 \quad$ Syariah Penal Code Order 2013 (No. S 69) (Oct. 22, 2013), http://www. agc.gov.bn/AGC\%20Images/LAWS/Gazette_PDF/2013/EN/s069.pdf [https://perma. cc/VUL5-W8QM].

2 One of the legal codes that came out of this was the Mohammedan Laws Enactment 1912.

3 Codification is "the act or process of arranging something, such as laws or rules, into a system." Codification, CAMbridge Advanced Learner's Dictionary \& TheSAURUs, https://dictionary.cambridge.org/us/dictionary/english/codification [https:// perma.cc/Q9FJ-R7SC]. 
Robinson refers to this form of lawmaking as "moral credibility": the local community is a moral authority that helps set the law and compliance norms for community behavior. ${ }^{4}$ The result allows for what the Brunei government aspires to achieve: a just system that can use internalized norms and social influence to benefit society by policing crime.

The first phase of the new Code covers what might be thought of as misdemeanors, and became law on May 1, 2014. That is, it set fines and prison terms for "non-ḥudūd" offenses, including some fifty-five "general offenses" with relatively minor penalties ( $\operatorname{ta}^{\prime} z \bar{\imath} r$ ), such as skipping Friday prayers, disrespecting norms for Ramadan, and the like. ${ }^{5}$

The next two phases, introduced on April 3, 2019, were more serious. The new Code includes more severe punishments under the rubric of hudūd (fixed criminal punishments and sentences) and qiṣa ș (murder and personal injury laws). These offenses range from apostasy and murder to adultery and sodomy as crimes. All are matters of life or death: each could result in the death penalty or imprisonment and fines depending on the severity of the crime.

More generally, the SPCO punishments are a combination of what might be called "misdemeanors" and "serious crimes." SPCO punishments are divided into the general, or ta' $z \bar{I} r$, offenses (defined as acts against society), hadd offenses (defined as acts against God), qișāș offenses (defined as retaliation or retribution for wrongful death or personal injury), and offenses of financial compensation (diyāt, badal al-sulh, and arsy (Arabic: arsh)). Most of the offenses under the SPCO draw on classical sharī $a$ crimes and penalties, though Brunei introduced new general offenses.

The procedures and structures governing these Codes are unique to Brunei. The law requires that stringent evidentiary conditions be met. The Syariah Courts Criminal Procedure Code Or-

4 Paul H. Robinson, Keynote Address at the University of Tehran on the Codification of Shari'a-based Criminal Law in Developing Muslim Countries (Mar. 6, 2019).

5 Refer to Parts I, II and III of the Syariah Penal Code Order 2013 (No. S 69), Oct. 22, 2013. 
der (SCCPCO) of 2018, which commenced January 1, 2019, makes provisions related to criminal procedure for Syariah Courts. ${ }^{6}$ Structurally, according to Attorney General Hairol Arni Abdul Majid, Brunei is the first to adopt the Civil Criminal Penal Code into the Syariah Criminal Penal Code. The two align in 95\% of the content, but the Syariah Criminal Penal Code differs on provisions for certain investigations and the use of confession. ${ }^{7}$

\section{The Strengthening of Procedure}

The main objective of criminal justice is to render justice in accordance with due process of the law. The SPCO gives Syariah Courts jurisdiction over criminal cases, within a dual or hybrid legal system in which legislation based on Islamic law and common law function concurrently.

What happens when one offense can be heard by a Syariah Court or a Common Law Court? The procedure of overlapping offenses under the jurisdiction of both Courts is as follows: ${ }^{8}$

- Investigation: Cases involving serious offenses such as theft, robbery, murder, causing hurt, and rape are to be reported to and investigated by the Royal Brunei Police Force with the assistance of other law enforcement agencies where relevant.

- Reporting \& Probable Cause: After investigation, the Investigation Paper will be submitted for evaluation by the Public Prosecutor with the assistance of the Chief Syar'ie

6 Syariah Courts Criminal Procedure Code Order (SCCPCO) 2018 (No. S 9) (Mar. 5, 2018), http://www.agc.gov.bn/AGC\%20Images/LAWS/Gazette PDF/2018/S009.pdf [https://perma.cc/KU9Y-RUH5].

7 Eileen Ng, Brunei Defends Move to Implement Syariah Law Amid Global Outrage, STRAits Times (Apr. 12, 2019), https://www.straitstimes.com/asia/se-asia/ brunei-defends-move-to-implement-syariah-law-amid-global-outrage [https://perma. cc/5VK8-VKTT].

8 Datin Hayati Pehin Mohd Salleh, The Special Lecture on the Enforcement of the Syariah Penal Code Order 2013 for Phase One, Declaration Ceremony of the Enforcement of the Syariah Penal Code Order (Apr. 30, 2014), http://www.agc.gov.bn/AGC\%20Images/downloads/speech/english.pdf [https://perma.cc/6QMB-ED3F]. 
Prosecutor if required. Assessment will be made as to the sufficiency of the evidence to prove the offenses under the SPCO 2013, or whether the suspect wishes to make a confession (iqrār) in accordance with the Syariah Courts Evidence Order (SCEO) of 2001 and the SCCPCO.

- Choice of Jurisdiction: By default, cases will go to Common Law Courts. If the evidence accords with the SPCO or a confession comes under the SCEO, the case will be transferred to the Syariah Courts for prosecution by Syar'ie Prosecutors with the assistance of Deputy Public Prosecutors, if required. Otherwise, the prosecution will continue under the Penal Code (Chapter 22) in civil courts.

On the one hand, the SCCPCO is specific in laying out punishments. The Order governs the conduct of investigation and prosecution as well as the role of the Syariah Court. The Order even graphically illustrates how several punishments should be carried out. $^{9}$

The difference in procedure from other Islamic law-implementing countries is seen in offenses that carry corporal punishment, such as whipping. In Brunei, the conditions for carrying out such a sentence are constrained by restrictions on carrying out punishments and limitations on accepting confessions. In Brunei, the enforcer of any punishment has to be of the same gender, and may use only moderate force-without lifting his or her hand over his or her head to ensure that no bones are broken or skin lacerated. ${ }^{10}$ While a perpetrator confessing to his crime would be one of the instances that could obviate the need to fulfill the witness and evidentiary requirement, the Brunei system calls for medical checks to make sure that anyone who confesses is competent to do so (i.e., that they are of sound mind), and it prompts or permits defendants to retract any confession at three designated points

9 Refer to Annex A for illustrations as shown in the SCCPCO 2018.

10 This is different from the images circulated in foreign media, where whipping sentences executed in public in areas such as Aceh, Indonesia, were conducted by a man on a female perpetrator. 
in the trial proceedings: before the trial starts, before sentencing, and before execution. The Code further allows defendants to withdraw their confession at any time, including during punishment. ${ }^{11}$ This is designed to ensure that no sentence would be carried out due to a confession.

Several government officials iterated that the high evidentiary threshold is difficult to implement. The Brunei law requires two or four men of high moral standing and piety as witnesses to meet the standard of proof of "no doubt at all" for all aspects of the penal crimes. ${ }^{12}$ Brunei seems to be embarking on a continuation of its pre-British protectorate practice of non-punishment, in line with Intisar A. Rabb's observation on doubt in Islamic law. ${ }^{13}$

\section{NATIONAL ENFORCEMENT OR MODERATION?}

There are reasons to suggest that the emphasis in the new Brunei code is on moderation rather than on strict enforcement. First, classical Islamic law norms require defendant protections, and so do Brunei's new laws-following those norms. I have already mentioned the principle of doubt above, the classical notion which Intisar A. Rabb explained in her book Doubt in Islamic Law and a modern example of which was codified in Brunei's new procedure code as a higher-than-reasonable-doubt standard of "no doubt at all." In addition, the Islamic law principle of proportionality in punishment would further ensure that this severe punishment be reserved for the most egregious cases. Moreover, forgiveness, mercy, repentance, and restitution are encouraged as alternatives to punishment.

Second are the procedural protections specific to the death penalty and the Sultan's recent declaration of a moratorium on its enforcement. The death penalty is not new under Brunei law, but it now has provisions to allow for commutation. While the death

$11 \operatorname{SPCO~} \S 86$.

12 "No doubt at all" is higher than the common law standard of "beyond reasonable doubt." See Ng, supra note 7.

13 Intisar A. Rabb, Doubt in Islamic Law: A History of Legal Maxims, INTERPRETATION, AND ISLAMIC CRIMINAL LAW (2015). 
penalty is present in the SPCO and SCCPCO, it is also present in the civil Criminal Procedure Code (CPC). Under the new Code, there are more ways for avoiding the death penalty. Imposition of the death penalty for murder upon the satisfaction of an extremely high evidentiary threshold can be avoided by a pardon from the next-of-kin of the victim or upon payment of diyāt (blood money) if requested by the next-of-kin. The Sultan can pay the diyāt if the accused cannot afford to do so.

Related is the Sultan's role in legislation and enforcement, which has guided the historical practice. Importantly, the Sultan, in a recent titah (royal decree), announced a de facto moratorium on the executions for capital cases under the SPCO, which provides a wider scope for remission. ${ }^{14}$ Brunei has moreover shown how, although the death penalty is present in legislation, both civil and Islamic ( $\operatorname{shari~}^{-} a$ ), it is rarely enforced and has not been enforced at all recently. The Sultan then made this de facto moratorium de jure in all cases.

Third, Brunei is bound to international obligations and has demonstrated willingness to revise legislation in response to reasoned debate and recommendations. Brunei is a small country that has thrived on its participation in regional and international fora, as a member of organizations such as the Association of Southeast Asian Nations (ASEAN), United Nations (U.N.), Commonwealth of Nations, Organisation of Islamic Cooperation (OIC), and Group of 77 (G77). Brunei is committed to observing international obligations in promoting and protecting human rights, and signals that it will continue to uphold obligations to international covenants on human rights such as the Convention on the Elimination of All Forms of Discrimination Against Women (CEDAW) and Convention on the Rights of the Child (CRC). Additionally, Brunei rejects all forms of torture, as well as inhumane or degrading treatment or punishment. In his titah in conjunction with the month of Ramadan, His Majesty proclaimed that Brunei would be

14 05.05.19 SPCO Clarified, Prime Minister's Office (May 5, 2019), http:// www.pmo.gov.bn/Lists/News/DispForm.aspx?ID=1188 [https://perma.cc/9QSF$5 \mathrm{XC} 8]$. 
ratifying the Convention Against Torture and Other Cruel, Inhuman or Degrading Treatment or Punishment (UNCAT). ${ }^{15}$

During the first session of the United Nations Human Rights Council Universal Periodic Review (UNHRC-UPR), several countries recommended that Brunei review its capital punishment legislation, even though it had a de facto moratorium status. ${ }^{16}$ This led to Brunei assembling an ad hoc committee and resulted in the addition of life imprisonment as an alternative to offenses that had previously warranted the death penalty. This process and outcome demonstrates Brunei's willingness to consider fellow nations' recommendations and those of the international community through deliberation and legislation. The country's eagerness to conform and to be a welcome member of the international community should be a testament to the idea that Brunei will not seek to enforce severe criminal punishments, and that it instead emphasizes that the punishments are more of a deterrent than a means to an end.

\section{WHITHER BRUNEI's NEW LAWS?}

The key to safe, defendant-protecting enforcement of an Islamic criminal justice system in Brunei depends on the codification of a uniform and clarified interpretation of Islamic law ( $\operatorname{sharī~}^{\top} a$ ), as well as sound procedural components outlined in the SCCPCO clauses-all within the national cultural context. It is yet to be seen how the Syariah Courts will implement the legislation, examine cases through either a civil or shari ${ }^{`} a$ lens, and determine the threshold by which the stringent evidentiary conditions and high burden of proof will be met. The next steps will be to elaborate and clarify the laws before and in the process of implementing them. 
ANNEX A: Graphic Illustrations Depicting How Corporal Punishments Should Be Carried Out, As Shown in the Syariah Courts Criminal Procedure Code Order (SCCPCO) 2018

Fifth Schedule: Whipping Rod [§ 179(a)]

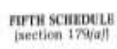

wiแurisc koD

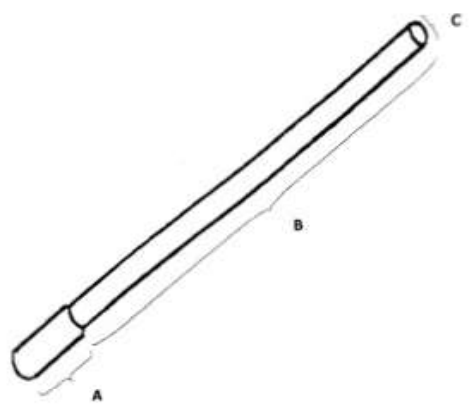

A. WHIPPNG ROD HOLDER
i. LENGTH OF WHIPPNO ROD - not exceeding 1.22 metres

Sixth Schedule: Execution of Sentence of Whipping [§§ 179(e)-(f)]

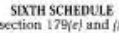
EXECUNON OF SEVTENCE OF WHIPPING
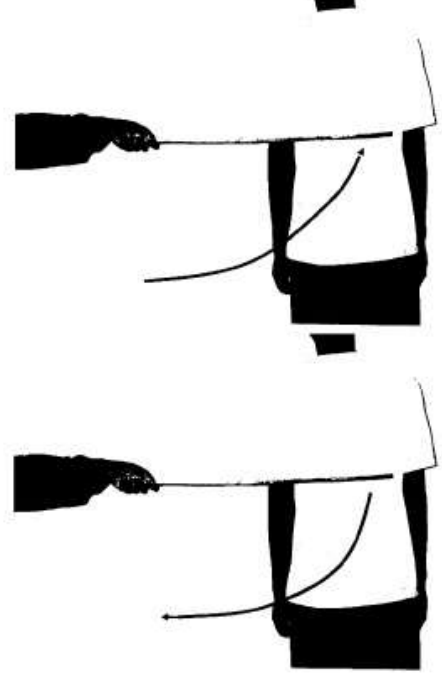